\title{
Rainbow Colour and Power among the Waanyi of Northwest Queensland
}

\author{
Paul S.C. Taçon
}

In 2002, an investigation into the rock art of Waanyi country was undertaken in conjunction with ongoing archaeological excavation. Various subjects, styles and techniques were documented, associated oral history from Waanyi elders was recorded and the relationship to archaeological deposits was assessed. A large number of rainbow-like designs, in red or red-and-yellow, were recorded, along with a magnificent and very large red-andyellow Rainbow Serpent. These and other images are discussed in relation to the travels of Ancestral Beings, stories and uses of coloured pigment and the use of local stone for both tools and the situating of important spiritual sites. Links to a network of other communities across northern and central Australia are highlighted. It is concluded that colour played a fundamental role in both expressing and maintaining relationships to places, Ancestral Beings and other groups of people. Important local differences can be seen in comparison to the ways in which colour has been used by Aboriginal people elsewhere. The research highlights ways in which the study of colour can prove valuable to archaeology globally.

\section{The importance of colour}

In recent years, there has been at times a 'colourful' debate about the origin and function of colour vision in primates, human ancestors, early humans and historic or contemporary peoples. In terms of the origin of trichromatic colour vision, that allows red hues to be distinguished from green, three main hypotheses are contested. The first is that colour vision developed in primates as the result of foraging, allowing them to see better and discriminate between edible and poisonous fruit and other food (e.g. Fernandez \& Morris 2007). The second is that it was selected for in order to see changes in skin, reflecting emotional states and sexual readiness (e.g. Changizi et al. 2006). The third hypothesis advocates that colour vision allowed early primates to see better and avoid snakes (Isbell 2006). Thus, colour vision developed in primates so they could avoid becoming snake food, could see different coloured foods or have more colourful sex. Perhaps two or all three factors played a role: for instance, Fernandez \& Morris (2007) argue trichromatic colour vision developed in primates in relation to foraging but was later used for sexual communication and other purposes. Whatever factor was ultimately responsible, it is fascinating to note that, among humans past and present, colour is universally significant in relation to food, sex and snakes, and there are many stories linking the three together in a colourful way. 'Adam, Eve, the snake and the apple' is one many readers are familiar with but many other links between food, sex, snakes and colour can be found cross-culturally, the case study below being an outstanding example from Aboriginal Australia.

From an archaeological perspective, colourful substances appear to have been important for humans and their immediate ancestors for hundreds of thousands of years (see Taçon 2006). In Zambia, for instance, the use of large quantities of red ochre is associated with the emergence of distinct stone tool technology 400,000 years ago (Barham 2002, 183). There was extensive use of colourful pigment between 200,000-300,000 years ago, leading Barham (2002, 188-9) to conclude that

central and East African hominids had incorporated color into their lives by 270,000 years ago, and this 
addition to their behavioural repertoire would remain a feature of the African archaeological record until the historical present.

At about the same time, the Neanderthal of Europe used pigment extensively, mainly manganese dioxide but also red ochre (Barham 2002; McBrearty \& Brooks 2000; Taçon 2006, 6). About 77,000 years ago, pieces of red ochre were engraved with geometric designs at Blombos Cave, South Africa (Henshilwood et al. 2002), highlighting the symbolic potential of ochre as substance and pigment. Evidence is now emerging across Australasia for early widespread use of pigment in a range of contexts by at least 40,000 years ago (Taçon 2005; 2006).

Despite very early evidence of pigment use across the world, including objects coloured red in Europe since at least the Solutrean (Osborne 1916, 408-14), colour has not been well studied archaeologically. Introducing a debate about the meaning of colour in early societies, Chris Scarre $(1999,109)$ argued that

Colour awareness and colour sensitivity must ... be an integral part of any archaeological analysis concerned with the development and nature of human cognition.

Since then, there have been few archaeological studies focusing on colour, with the notable exception of Colouring the Past (Jones \& MacGregor 2002). Cole $(2005,76)$ begins a review of the book by asking 'Why has it taken so long for archaeology to undertake a critical treatment of colour?'. There are many reasons but the crucial issue Colouring the Past highlights is that colour is important for archaeology and investigations of the past everywhere. As Cole $(2005,77-8)$ concludes:

recurring issues involving colour are of global interest: colour as a temporal and spatial component of the natural environment; culturally specific colour terminology and selectivity as a source of insights into the processes of symbolisations and categorisations; the universality of the restricted colour palette; the introduction of novel materials as a source of new colour perceptions and selection; the importance of attributes (other than hue) such as texture, luminosity, hardness, brightness, darkness and light; colour perceptions in the use of stone (e.g. quartz) and metals (e.g. copper); the meaningful, deliberate and contextual construction of colour and other qualities, as in technical transformations to achieve lustre.

In this article, all of these issues are discussed with the perspectives of north Australian archaeology and ethnography in order to provide points of similarity or difference to be explored by other researchers working in various parts of the world and to offer a concrete example. This is important, as, although colour has meaning(s), 'Colour cannot have influence in itself but must always be subordinate to form and substance, and meaning is learnt through this route' (Young 2006, 178). Form and substance are criteria archaeology commonly deals with as a means of getting at meaning. Adding colour to the mix thus opens a whole new dimension for the exploration of meaning.

\section{Colour and brilliance}

Colourful, shiny and bright things play prominent symbolic roles in many Australian Aboriginal societies. Objects, creatures and Ancestral Beings with intense colour and, or, brightness are considered particularly powerful. Ochre has been especially significant in this regard since people first arrived in Australia, 45,000-60,000 years ago, with various forms of haematite and other pigment considered especially potent. Used pieces of ochre can be found at numerous excavated sites across Australia, including burials, securely dated from over 43,000 years ago (e.g. at Lake Mungo: Bowler et al. 2003). Some ochre was highly prized and traded over vast distances and many ochre mines were used for millennia (Taçon 2005). Other powerful substances include quartz and various bright or colourful minerals, seemingly especially valued in mid to late Holocene times. For instance, in both northern (Taçon 1991) and southeastern Australia (Brumm 2005), certain types of colourful stone were chosen to make the most significant stone tools, such as long lauwk quartzite blades or axe heads, because they were the most bright and colourful - and thus the most powerful. Cross-hatched in-filled bark paintings and body art (Morphy 1989; 1991; Taylor 1996), elaborately painted objects and skeletal material and some contemporary acrylic paintings are considered especially significant if they radiate brilliance and colour.

Colourful creatures used symbolically to convey complex ideas about life and death include fish and snakes, animals with rainbow colour in their scales (Taçon 1989a,b). Rainbows and Rainbow Serpents are among the most outstanding examples of things both intensely colourful and powerful, whether seen in the sky or below waterfalls, depicted at rock-art sites, painted on bark or paper, enacted in ceremony or described in oral history (e.g. Taylor 1990). Today, Rainbow Serpent imagery, stories and significance is expressed almost everywhere in Australia, although forms and details vary. The oldest surviving depictions of Rainbow Serpents are from western Arnhem Land, with numerous examples inferred to be 4000-6000 years old clustered around the Alligator Rivers (Taçon 
et al. 1996). More recent rock-art depictions can also be found there, and right across northern Australia, with elaborate stories, ceremonies and Dreaming tracks linking depictions to sites and landscapes stretching across vast distances.

Connected aspects of belief, oral history, ritual, stone-tool making, geological landscapes and depictions of Rainbow Serpents feature strongly among the Waanyi of northwest Queensland, although this has not been explored in much detail until now. A fascinating feature of the Waanyi Rainbow Serpent complex is that the very nature of stone landscapes in Waanyi country has influenced the way Rainbow Serpents should be depicted. In this article, links between stone and serpents are explored in the context of rock art and contemporary ideas about colour. The geographic focus is the greater Riversleigh region of Queensland, which includes the Riversleigh World Heritage Area, Riversleigh Pastral Holding and the southern part of Boodjamulla (Lawn Hill) National Park (Fig. 1). In 2002, fieldwork was undertaken with Waanyi elders and young cultural heritage trainees as part of a larger archaeological investigation.

\section{Rock-art survey and recording}

The Riversleigh World Heritage Area has long been renowned for its abundant fossil fields. Despite the intensity of palaeontological research, limited archaeological investigation has taken place until recently. Previous studies highlighted the significance of Colless Creek, Lawn Hill Gorge and some areas to the north, both for archaeological deposits and rock art (e.g. Border 1988; 1989; Hayes \& Border 1997; Hiscock 1988; Walsh 1982; 1985). Some initial archaeological work was done at Riversleigh in the 1990s (van der Meer 1997) but large-scale survey, excavation and ethnography did not begin until 2001. This project, a joint venture between the Waanyi Aboriginal Community, the University of Sydney, the Australian Museum and the Queensland Environmental Protection Authority, was designed to address questions of national and international significance, as well as to make recommendations on conservation and to offer training.

In 2002, the greater Riversleigh area was surveyed for shelters with rock art and, or, deposits with excavation potential as well as other significant archaeological sites. Waanyi elders and, or, trainees assisted with surveying, recording and interpretation. Work was concentrated on either side of the Gregory River but surveys were also conducted near the O'Shanassy River, at Lilydale Spring, south of

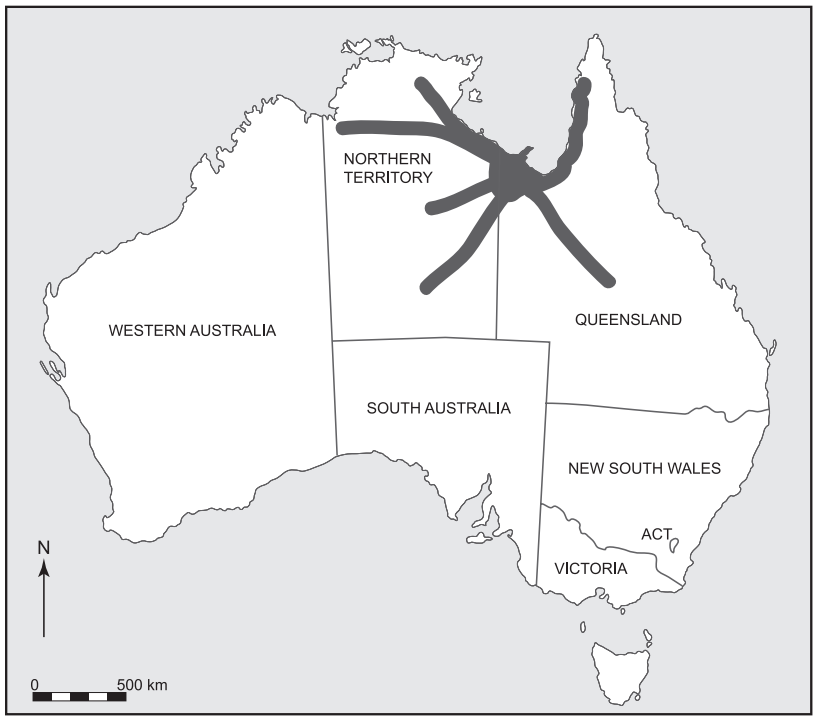

Figure 1. Australia: extent of Waanyi county and major Dreaming tracks associated with Rainbow Serpent and Dingo Ancestral Beings mentioned in the text.

Lilydale Spring, within the World Heritage Area behind an area known as 'D Site', along Verdon Creek, at Verdon Rock, north of the Gregory River, east of the Lawn Hill road, east of the O'Shanassy River and along Victor Creek. Brief visits were also made to Rainbow Dreaming and Wild Dog Dreaming in Lawn Hill Gorge, and to two sites near Musselbrook Ranger Station, in the 'Amphitheatre' gorge to the north and near Ridgepole Creek and Waterhole, to the south-east. Most survey was on foot but some parts of the upper Gregory River were reached by boat or helicopter.

33 locations with rock-markings were recorded in detail, mostly paintings but also some stencils, prints, scratch designs, abraded grooves and grinding hollows. 370 rock-art designs were recorded, not including patches of pigment or undecipherable fragments, from 33 sites (average of 11 designs per site). They comprised 262 paintings, 28 dry pigment or drawn designs, five adult hand stencils, one child's hand print, 31 pecked petroglyphs, eight scratched designs, one axe-grinding groove, and a cluster of 34 grinding grooves and hollows. Paintings, mostly in red, were found at 30 sites. Dry pigment designs (red or black) were found at ten. Three sites have scratch designs (two with scratch marks over red pigment), two sites have pecked petroglyphs, two have abraded grooves or hollows, one has a child's hand print and one has adult hand stencils. 28 sites were recorded in the greater Riversleigh area, with eight in the World Heritage Area. 
A detailed analysis of the pigment art was undertaken. The most common subject is bird tracks (57 for the Riversleigh region, 62 for all sites), followed by snake-like motifs (13 for Riversleigh, 19 for all sites) and lizard-like motifs (12 for Riversleigh, 18 for all sites). Other reptiles, such as turtles and crocodiles, were also depicted, as were mythological reptilian Beings, such as Rainbow Serpents (identified both through contemporary oral tradition and formal analysis) and Rainbow Arcs (four for Riversleigh, nine altogether). Preliminary analysis suggests a unique Riversleigh corpus that is part of a larger Gulf 'style' that has influences from the north, west and southwest (Border 1988, 80-82; Border 1989, 57; Morwood 1977; Walsh 1985). The sample is both comprehensive and representative although there are probably more sites in the remoter parts of Riversleigh, especially in the far upper reaches of the Gregory. At some sites, oral history about the site, larger landscapes and associated Ancestral Beings was recorded.

\section{Rainbow Serpents, landscapes and stone}

According to contemporary oral history, the largest and most significant Waanyi Rainbow Serpent painting is at Lilydale Spring, in the Constance Range sandstone belt, immediately north of Riversleigh limestone sites (Figs. 2-3). Boodjamulla is the local name for the region. It also is the name for the Rainbow Serpent, one of the reasons the surrounding park was renamed Boodjamulla from Lawn Hill. The Waanyi name for Lilydale Spring, including the painted panel and the rock above and below, is Jingari. It faces north, with the rock-art site located above a ledge near the top of the escarpment. Most of the Rainbow Serpent is protected from rain water by a natural curved crack in the rock. The Serpent is fully exposed to the sun for much of the day in winter but, because of the extensive use of fine pigment, it survives remarkably well and can be seen from a few hundred metres.

The red-and-yellow Rainbow Serpent is 5.8 metres long by 2.3 metres high and is in the centre of a panel created by a deep and wide natural split in the rock that is a Rainbow shape itself. The Serpent is composed of several alternating bands of red and yellow, with its body forming a series of three large arcs before a raised head. Each of the arcs is similar to Rainbow designs elsewhere in the region but the resulting composition at this site produces a very dramatic effect.

The painting is located directly above Lilydale Spring and there is a source of what Waanyi consider to be an especially potent form of red ochre on the ridge directly above. Various stone flakes, cores and tools, mostly of chert, can be found in the creek near the spring but no lithics were observed on the surface of the small floor or ledge below the Rainbow Serpent paintings. Some lithics there and in scatters to the south have rainbow-like bands of colour (Fig. 4). This banded chert is similar to material found in nearby Gregory River gravels and to the west of the study area, on the Barkly Tableland (Moore 2003). Among other things, it was used in making wood-working tools or tulas during the late Holocene (tulas are unique to Australia; the earliest are about $2700-3600$ years old: Mulvaney \& Kamminga 1999, 248-51; Moore 2004). Banded chert fractures unevenly but has interesting colour patterns (Moore 2004; Peter Hiscock pers. comm. 2007). Excavations to the north and south of Lilydale Spring (Hiscock 1988; Slack et al. 2004; 2005) showed that banded chert was used in the Holocene but at the excavated sites they are rare as plentiful local chert was more commonly used. For the northern end of the study area, some excavated deposits with banded chert are no more than 6000 years old and Slack et al. (2005, 57) argue there was a 'reconfiguration' of Aboriginal settlement with 'the amelioration of ENSO conditions after 3500 years BP as larger permanent water supplies became available'. To judge from relationships to excavated sites, subject matter, condition, style and colour, much of the coloured rock art mentioned in this study and noted previously by others appears to be mid to late Holocene too.

At the base of the escarpment, both in and around the creek, are numerous boulders with brightly coloured bands of colour (Fig. 5). These vary from stones an individual could pick up to rocks weighing hundreds of kilograms. The top of the escarpment above the Serpent also has lengthy natural bands of colour running through the rock (Fig. 6), perhaps suggesting where to place a similar painting below. Other art designs nearby include a dry red oval shape $(32 \times 13 \mathrm{~cm})$ with a 'restricted men's business' story and a dry red line $(49 \mathrm{~cm})$. They are located around a corner, about nine metres east. To the immediate east are at least five very large yellow hand stencils. To the northeast, on the plain and in the creek, are some women's sites forbidden to men.

Waanyi elders, Richard Brookdale and Jackson Diamond, said the old people painted the Jingari Rainbow Serpent, that it did not paint itself. They put it there so everyone would know about it, so its story would be told and not forgotten. Eric King, another key elder, said that this Rainbow Serpent travelled over much of northwest Queensland, starting at Aurukun before travelling to various places including 
Edward River, Mornington Island, Doomadgee, Nadjibarra (near Hells Gate and Wollogorang in the Northern Territory) and Lawn Hill. It stayed at Jingari for a while before moving on to Alexandria and then back to Nadjibarra, in the Northern Territory. Another Rainbow Serpent is said to have travelled across the Northern Territory from beyond the Victoria River (see also Dymock 1982; 1993). Besides Rainbow Serpents, various other Ancestral Beings, such as Kangaroo and Catfish from Alexandria, Emu from the Northern Territory, connect the people of Boodjamulla with other people and places as far as Alice Springs, Tennant Creek, the Kimberley and Arnhem Land to the west and to various locations to the east and far southeast. Particularly strong Dreaming tracks of several creatures link Boodjamulla National Park with Doomadgee and Mornington Island. Thus, in many ways, Boodjamulla-Riversleigh can be considered as a key junction for significant Dreaming tracks that run across great stretches of northern Australia (Fig. 1).

There are a number of other locations with Rainbow Serpent or Rainbow-like designs within and beyond Waanyi territory, including north of Musselbrook Creek, in Lawn Hill Gorge and along the Gregory River. Rainbow Dreaming, Lawn Hill Gorge, is one of the better-known sites (Fig. 7). Consisting of an exposed panel with one large painting of a double rainbow design, two concentric yellow arcs with red outlines, it is at the base of a cliff. Waanyi interpret it as the Rainbow, Gungma. As Walsh $(1985,148)$ notes, the 'site is referred to as "Rainbow Dreaming", and is associated with Boodjamulla the Rainbow Serpent, which lives in nearby Duwadari waterhole'. Boodjamulla is said to have created the gorge and all its waterholes. If it were to leave so too would the water according to the Waanyi. In the early 1980s, Waanyi Joongai Arthur Petersen told Grahame Walsh $(1985,109)$ part of the story:

Boodjamulla is described by Arthur as 'great big one', 'like a big catfish', and 'brown like a fish'. The entire Lawn Hill Gorge area is collectively referred to as Mumbaleeya, or Rainbow Serpent country. No waterholes or permanent water are believed to have existed in the area before the coming of Boodjamulla. He created Lawn Hill's deep gorge holes and now keeps them full of water to keep his body wet; if he ever leaves, the waterholes will dry up ... There appears to be a separate resident Rainbow Serpent in Louie Creek, while the Duwadari, Jaluwadari and Luluwalla waterholes of Lawn Hill are occupied by one serpent ... Considerable respect is given to the Gungma painting in BLA 8804, and the warning is proferred that if anyone touches or interferes with this art Boodjamulla'might be do something to them, make them sick.

Walsh recorded five similar pictures interpreted as Rainbows from three other sites. Four are yellow with red outlines, one of which is a double arc. The fifth is monochrome red with four closely spaced arcs as well as scratched outlining and infill (Walsh 1985, figs. 76-80). Walsh recorded a few other sites containing boomerang motifs and at one an ambiguous design can be interpreted either as a Rainbow or a boomerang. Hayes \& Border (1977) recorded several crescent and other curved designs along Elizabeth Creek, including one painting of a Rainbow design with alternating bands of red and yellow. Border (1989) notes 'crescent' shapes at a number of sites elsewhere on Lawn Hill Station and along creeks to the north. Most are red but one measuring about 1.5 metres in length is yellow with a red outline, sandwiched between two other layers of art (Border 1989, 34).

Re-occurring motifs which link individual sequences together from Lilydale Springs to Elizabeth Creek are crescent shaped motifs, bichrome snake motifs and crocodile/lizard representations ... The two former types are described as being associated with important ceremonies (Walsh 1985) and provide some basis for assuming that Aboriginal groups inhabiting the region probably shared common ritual/ceremonial traditions (Border 1989, 58).

Morwood (1977; pers. comm. 2004) reports similar motifs to the south and west of the Riversleigh study area. Red-and-yellow bichromes were also made by Kalkadoon people to the southeast to represent Ancestral Beings and men painted with feathers for ceremony (Davidson 1993). As with the greater Riversleigh area, bird tracks also figure prominently.

The 2002 survey located another four previously unrecorded Rainbow designs from three sites, along with many snakes and other curvilinear paintings. These include a mulberry composite human-snake from north of Musselbrook Creek (Fig. 8), a red Rainbow with three nested arcs, a red Rainbow arc and a large red-and-yellow panel of undulating bands of vertically oriented paint. The latter is very faded but may be a sizable Rainbow Serpent, similar to the one from Lilydale Spring or another Ancestral Being painted in a style similar to Arrernte central desert Atywerrenge designs (Gunn 2003). Its size, bichrome colouring and form all suggest it is a Dreaming and ritual site that likely was rejuvenated. A sizable cache of bright yellow ochre was located in a large crevice close to the site similar to that used for part of the painting. 


\section{Waanyi Rainbows and Arnhem Land}

Colour is important in these and other ways for many groups across northern Australia. This is especially true of Arnhem Land. Western Arnhem Land appears to have the oldest surviving depictions of Rainbow Serpents and probably contains more than any other region (Chaloupka 1993; Taçon 1989b; Taçon et al. 1996). Invariably, they are composite beings, made up of body parts of many key creatures. Sometimes they even have human elements like the Waanyi Rainbow Serpent north of Musselbrook and a 17 $\mathrm{m}$ Rainbow Serpent in the Laura area of the Cape York Peninsula. A particularly significant example with human female attributes is located in Deaf Adder Gorge, Kakadu National Park (Chaloupka 1993, fig. 37; Taçon 1989c, fig. 10). It is reminiscent of the Waanyi Musselbrook Rainbow Serpent and, indeed, the Musselbrook composite snake-human female appears to have an Arnhem Land influence (Musselbrook Creek's headwaters lie in the Northern Territory). The traditional story associated with it is very similar to a Waanyi Rainbow Serpent story. In the Deaf Adder/Gundjebmi story, a father, Gulinj, the Flying Fox Ancestor, rescues his two boys after they were swallowed by the Rainbow Serpent. Gulinj cuts open the Rainbow's body to release the boys, using a sharp stone axe (Chaloupka 1993, 48; Chaloupka et al. 1985, 80-82; Taçon 1989b, 263-4; Taçon et al. 1996, 117-20). Among some Gundjeihmi, it was a dollar bird that cut open the Rainbow Serpent with a stone axe. For other Arnhem Landers, blue-winged kookaburras and other birds were released from the Rainbow Serpent. In the Waanyi version, the two boys became colourful green and red parrots (red winged parrot, Aprosmictus erythropterus). Richard Brookdale said two boys were mucking around on an island somewhere in Arnhem Land. The Rainbow was upset, so he came and swallowed them. Their father came looking for them but could not find them. He saw the Rainbow and thought it might have swallowed them so he cut its guts open with a stone knife and stone axe. Then the two green and red parrots flew out. The Rainbow had changed them.

Could Waanyi Rainbow Serpent iconography have influenced western Arnhem Land? Certainly, there are Dreaming tracks linking peoples across these stretches of country and the Waanyi language is part of a set of non-Pama-Nyungan languages that stretch from their region across most of Arnhem Land, the Victoria River region and the Kimberley (McConvell \& Thieberger 2005, fig 7.1). Remarkably, there is a very well known Rainbow Serpent near the East Alligator
River (Fig. 9), Kakadu National Park, different from all other Rainbow Serpents in Australia except those of the Waanyi. Walsh $(1985,109)$ was the first to remark on the similarity between it and a design at Gungma (Rainbow Dreaming), but it also resembles the large Serpent at Jingari and others in Waanyi country.

The East Alligator painting is in one of the main galleries accessible to the general public at Ubirr (Kakadu National Park), about 600 km northeast of Boodjamulla. It was first published by Mountford (1956, 214-15) as an Ancestral water snake (file snake) called Aniau-tjunu. Not a composite being, like other Arnhem Land Rainbow Serpents, it consists of a two metre horseshoe-like arc with alternating bands of red and yellow. Mountford was told the snake came with its family from Matjili lagoon, to the northwest. The snake is reputed to have left its image on the rock after deciding this was a good place to stay. The snake family went inside through a rock crevice, emerging at night for food. Mountford $(1956,214)$ was also told the painting was an increase site:

When the aborigines want to increase the supply of
water-snakes in the lagoons they choose the correct
season, and standing before the painting, beat it
lightly with a bough to hunt out the spirits of the
water-snake, directing them meanwhile to go to the
various waterholes and there become large water-
snakes. By means of this simple magical formula
the aborigines believe that there will be an adequate
food supply.

The painting has been interpreted as a Rainbow Serpent by Gagudju and other elders (Taçon 1989b), with various names such as Kalarrabirri (Gillespie 1982) and most recently Garranga'rreli (Department of Environment \& Heritage 2006).

\section{Wild Dogs, colour and change}

Besides Rainbow Serpents, some of the most significant Waanyi Dreaming stories involve Wild Red Dog and Wild White Dog, two ancestral Dingos. Wild Red Dog is from the tableland south of Lawn Hill but the gorge contains its most significant Dreaming site, Warde or Badjenung. It travelled north to Louie Creek before stopping at Lawn Hill Gorge. It later went north to a swamp at Doomadgee and then on to Mornington Island. That is where it stayed in the end. At Lawn Hill, Wild Red Dog met Wild White Dog before the latter went west to Alexandria, southeast to Winton and then further east to Longreach where it ended its journey. Both have very big stories, stories Waanyi elders claim are similar and linked to those from Alice Springs and Tennant Creek (e.g. opening 


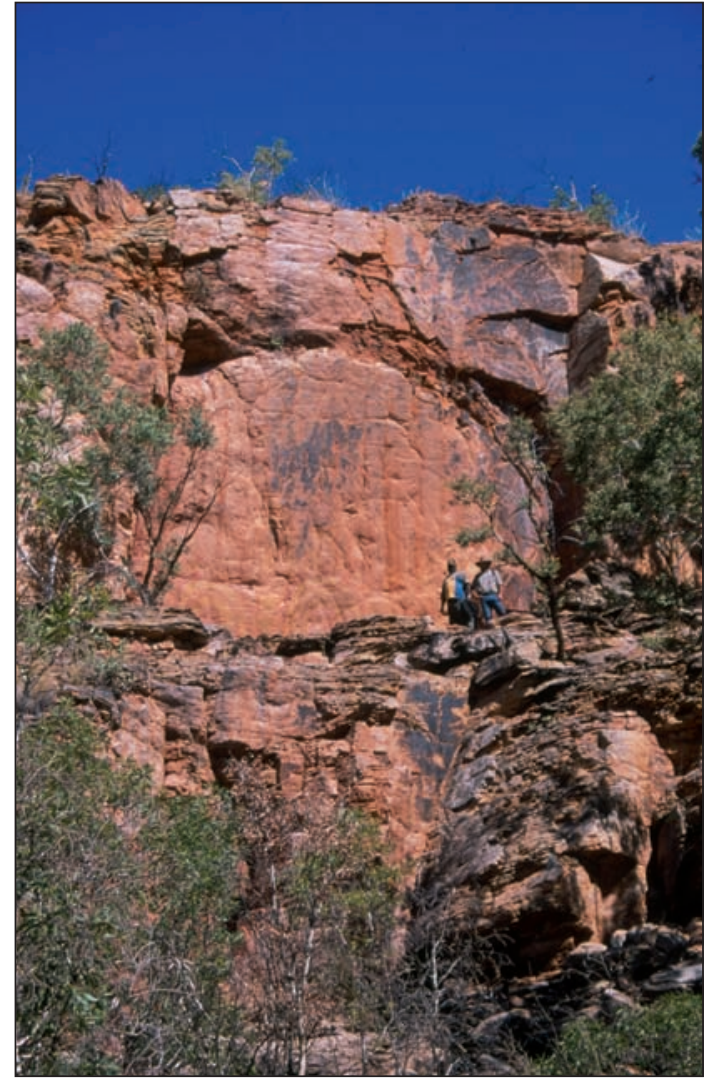

Figure 2. The Lilydale Spring Rainbow Serpent is the largest rock-art depiction in the Riversleigh-Boodjamulla area and can be seen from hundreds of metres away. It is located above the ledge and to the left of Gadrian George and Adam Brumm.

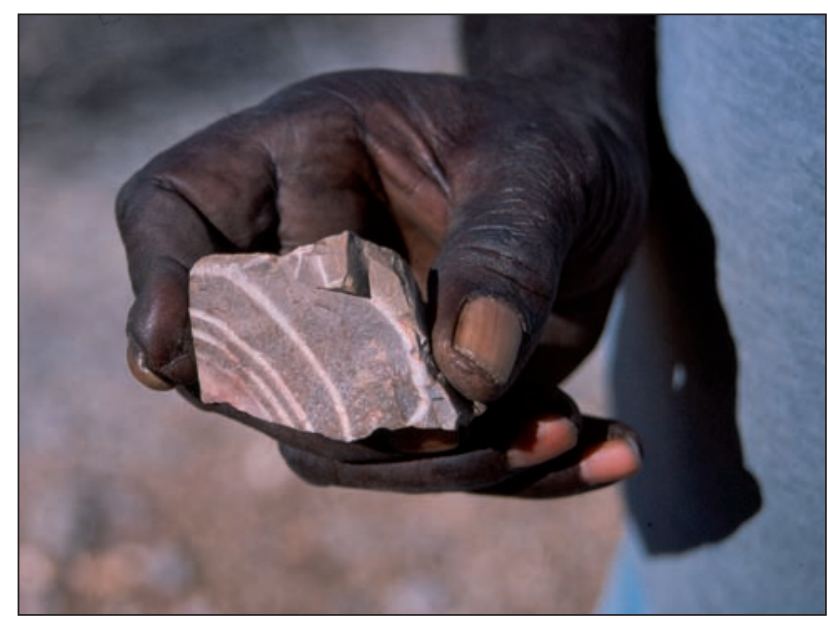

Figure 4. Some stone tools were made from banded chert. This flake has curved rainbow-like colour in a form similar to some rock art.

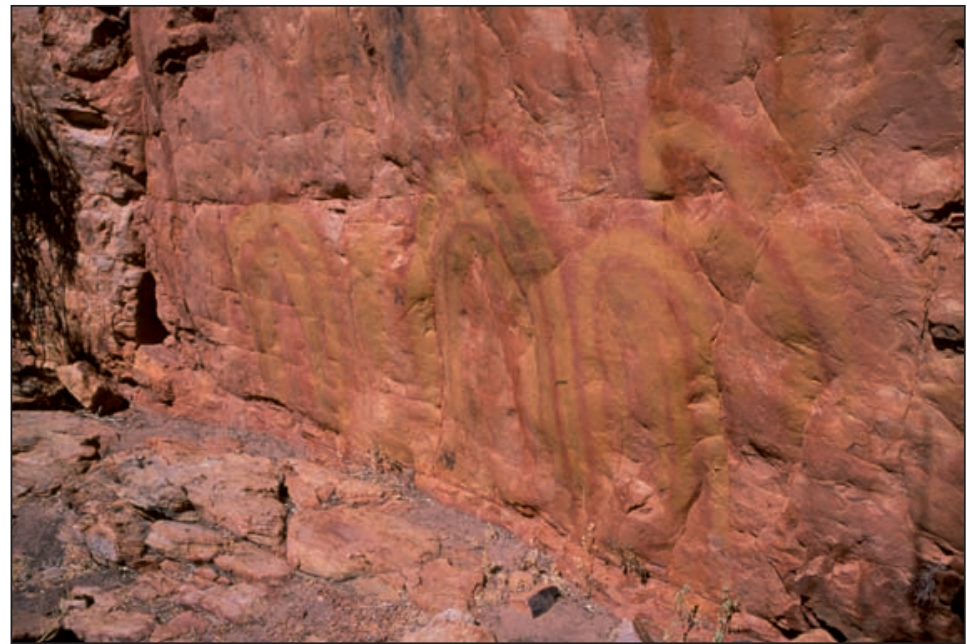

Figure 3. At Lilydale Spring, the Rainbow Serpent was formed by painting undulating bands of red and yellow attached to a huge snake-like head that rises up from the base of an elevated sandstone ledge (5.8 $\mathrm{m}$ long $\times 2.3 \mathrm{~m}$ high).

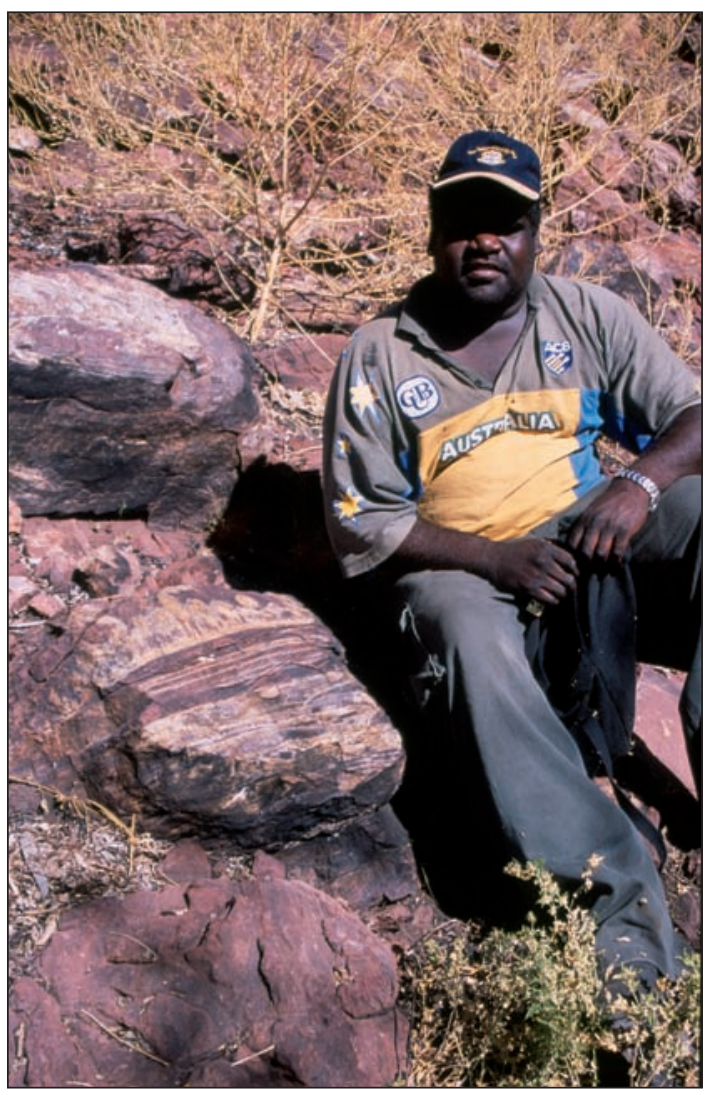

Figure 5. Many large boulders with alternating bands of colour can be found below the Lilydale Spring Rainbow Serpent, near the permanent spring itself. Here, Gadrian George sits next to a sizeable outcrop. 
story from Alice Springs in Us Mob 2006). Some details are restricted but it is common knowledge that Red Dog got the best of White Dog, taking his sister to Mornington Island after winning a big fight (the Alice Springs story also features two wild dogs fighting over a female). Significantly, in Waanyi country, Red Dog made powerful red ochre jidijidi while White Dog made white ochre (pipe clay) jidijidi. Jidijidi is a term used for the most brilliant, potent and powerful red or white pigment that is sought after for love magic. An especially good source of red jidijidi is said to lie above the Jingari Rainbow Serpent.

At the Lawn Hill Gorge Wild Dog Dreaming site (called Warde or Badjenung in Waanyi), there is much rock art, from old patinated pecked circles, dots and line designs to various red paintings and red drawings, including in-filled ovals and bird tracks. There also are two yellow Rainbow designs and a double arc Rainbow in yellow. The site is open to the public and an interpretation sign reads as follows (see also Walsh 1985, 109-10).

These paintings are said to represent arch-shaped objects held by performers in the wild dog or dingo dance. Known as maargoondoo, these are believed to have been sticks decorated with bark and string.

Upon questioning, Jackson Diamond said maargoondoo is the name for message stick. He and Richard Brookdale provided a detailed interpretation of the rock art at Wild Dog Dreaming, much of which had to do with incest taboos and the teaching of proper human sexual relationships, in contrast to that of dogs. It would be improper to reveal the full story here but it is important to note that the key story relates to rules of human procreation. This links back to the use of pigments created by the dogs for attracting members of the opposite sex. The shape of the maargoondoo sticks is similar to rainbow shapes, reinforcing a further connection to creativity and colour.

A number of Waanyi said that, in order for jidijidi to work for a man, he has to shave and rub it on his face to attract a woman. Then he says her name and, when he next sees her, she might come up and kiss him. Some thought the red jidijidi was more effective than the white while others thought both equally powerful. Some said men preferred red while women preferred white. Among the Alawa people, to the west, white pigment and White Dog are important and they say negative things about red and Red Dog while, to the east, the Kalkadoon hold the red and Red Dog story as the best for jidijidi (Adam Brumm pers. comm. 2002). For the Waanyi, in the middle, both are important, reinforcing the notion of their country as a significant cross-over place. Indeed, for the Waanyi there are very strong links between Rainbow Serpent stories, Rainbow Serpent rock paintings, unusual geology, some lithics, the Wild Red Dog story, the Wild White Dog story, red ochre, white pipe clay, love magic and procreation. Colour, especially bands of colour (as in geology, banded chert lithics, rainbows, Rainbow Serpent designs) or pure, brilliant colour (red and white jidijidi) is especially significant as it links everything - of the past, present and future - together. Colour, as expressed through these things, is the key to understanding important aspects of cultural landscapes, ritual, social processes, inter-tribal relationships and cosmology. For instance, aspects of colour connect Waanyi to other people, other species, landscapes and Ancestral Beings.

Among traditional peoples of western Arnhem Land, Rainbow Serpents living in water, especially at the base of waterfalls, are said to have a pair of 'dogs' (djangerrg) as companions (Chaloupka et al. 1985 , 86). Depictions of thylacines in old rock art are identified today as images of the Rainbow Serpent's dogs (Chaloupka 1993, 50-52; Taçon 1989b, 265). But this association must have a lengthy history as, at one site in southern Arnhem Land, there is a rare painting of a Rainbow Serpent in 'dog' form - snake body with dog-like legs and a thylacine or dog-like tail and head - that appears to have great antiquity, possibly over 4000 years, because it has attributes similar to other Arnhem Land paintings inferred to be at least that old (Gunn \& Whear 2007, 12). Across Arnhem Land there also is a strong association between wallaroos and Rainbow Serpents (e.g. Chaloupka 1993, 50), with some stories involving cutting, stone knives and so forth similar to those of the Waanyi. For instance, among the Waanyi, the Red Kangaroo Ancestor gave the Flying Fox Ancestor a stone knife for circumcision and taught the Flying Fox people new laws (Dymock 1982, 5). At another locality, it changed into a Gray Kangaroo. Later, dogs followed the Red Kangaroo, attacked and killed him. According to those consulted by Dymock $(1982,7)$, the Dingos cornered him up Gorge Creek before tearing out his guts and spilling his blood on the ground. According to others, the Kangaroo fell into the water and was killed there by the wild dogs.

These connections also extend across to the Kimberley, with Wild Dogs especially important symbolically. As Rose $(2002,7)$ notes,

Right across Australia Dingos are important dreaming personages - their tracks and stories are major connecting links, and they figure in major songs and ceremonies.

For the Yarralin of the Victoria River region (Rose 2002, 7; see also Rose 1992), 
there was a time when Dingos and Humans were all one species. We have now gone in separate directions - one dog direction and one human direction - but we are sometimes like siblings, being descended from ancestral Dingos.

\section{Colour, climate change and meaning}

About 4000 years ago, the first Rainbow Serpents are inferred to have become widespread in rock art (Taçon et al. 1996) and dingos were introduced to the Australian continent (Corbett 2001). Soon after, by about 3000 years ago, rising sea levels finally stabilized. Dingos first appear in the archaeological record in what some people consider to be the context of purposeful burials. Later, in northern Australia, dingo bones were sometimes rubbed with red ochre, as with human bones prepared for secondary burial (Taçon \& Pardoe 2002, 60; Morey 2006). Both rising sea levels and dingos initiated many different forms of change to fauna, ecosystems and human environments. Among other things, changes to climate meant rainbows may have appeared more frequently in the sky while dingos drove native dog-like creatures, such as thylacines, to extinction on the mainland. Oral history, ritual and visual art all highlight the Rainbow Serpent as one of the most powerful forces. Beginning about 4000 years ago, rock art itself underwent major transformation across Australia, especially in the past 2000 years. Other changes in culture also took place, for example the introduction of spear-throwers, the spread of stone points, changes to language, and warfare (see Haskovec 1993; Lewis 1988; McConvell 1996; Mulvaney \& Kamminga 1999; Taçon \& Chippindale 1994). However, the precise timing and rate of change varied from place to place with some changes beginning in northern Australia early on but not occurring elsewhere until one or two millennia had passed. Taçon \& Chippindale (in press) argue there was also a general shift from a more shamanistic ideology to a more totemic one - although this idea is contentious among Australian archaeologists or rock-art researchers. A core of belief, expressed in art traditions involving human-animal composites, was maintained (Taçon \& Chippindale 2001).

Among the Waanyi, Dingo Ancestors created love magic in the form of brightly coloured red or white pigment. This pigment is said to encourage human procreation. From beyond Arnhem Land to Waanyi country, Rainbow Serpents, dogs, large macropods, flying foxes, colourful birds, stone knives, blood and pigment are linked together in story, song, ceremony, visual art and landscape. They are associated with fertility, reproduction, initiation and transformation but, for these results, there must be ancestral power, symbolized and represented by bright colour. As Young $(2006,173)$ notes for humans everywhere,

Colours animate things in a variety of ways, evoking space, emitting brilliance, endowing things with an aura of energy or light.

For the Waanyi and other north Australian groups, a world without colour would be no world at all. For bright colour, as a form, symbol and expression of Ancestral power, not only powers the world but also brings it to life.

How old are these beliefs? Certainly, all the evidence supports the idea that the interrelationship between Waanyi, Ancestral Beings (particularly the colourful Rainbow Serpent), specific places, other species, brightly-coloured pigment, banded chert, creation, procreation, rock art and so forth is less than 3500 years. It was at this time that large permanent sources of water became available but, beginning about 1000 years ago, a pattern of seasonal inundation of various areas was established (McGlone et al. 1992). David (2002) has argued that most Australian Aboriginal oral history, Dreamtime symbolism and related practice is no more than 1000 years old, while Taçon et al. (1996; Taçon \& Chippindale 2001) contend the roots of some traditions of western Arnhem Land extend back 4000-6000 years or further. The Waanyi complex probably also has some old roots, perhaps evidenced by the oldest Rainbow Serpent rock painting, which is in composite form, like those of Arnhem Land, stories of dingos and the increased use of banded chert. But much of the complex is probably relatively recent, associated with the climate and landscape of the past 1000-2000 years. Indeed, it appears that most of the rock art dates to this late Holocene period, given its exposure, state of preservation, subject matter and colour.

Complicating the picture is the nature of contemporary ethnography. First of all, everything is given meaning in the present, with old things re-interpreted. Thus, information obtained through ethnography is necessarily contemporary and may be quite different from meaning ascribed 50, 100, 500 or 1000 years ago. However, ethnography can generate hypotheses to be tested against other forms of evidence, such as the archaeology of the ground and that on shelter walls, environmental records, and so forth. Furthermore, a 'core' of meaning can sometimes be extracted from ethnography by comparing what people have to say on particular topics from across a region and at different points in time (Taçon 1992). 
Paul S.C. Taçon
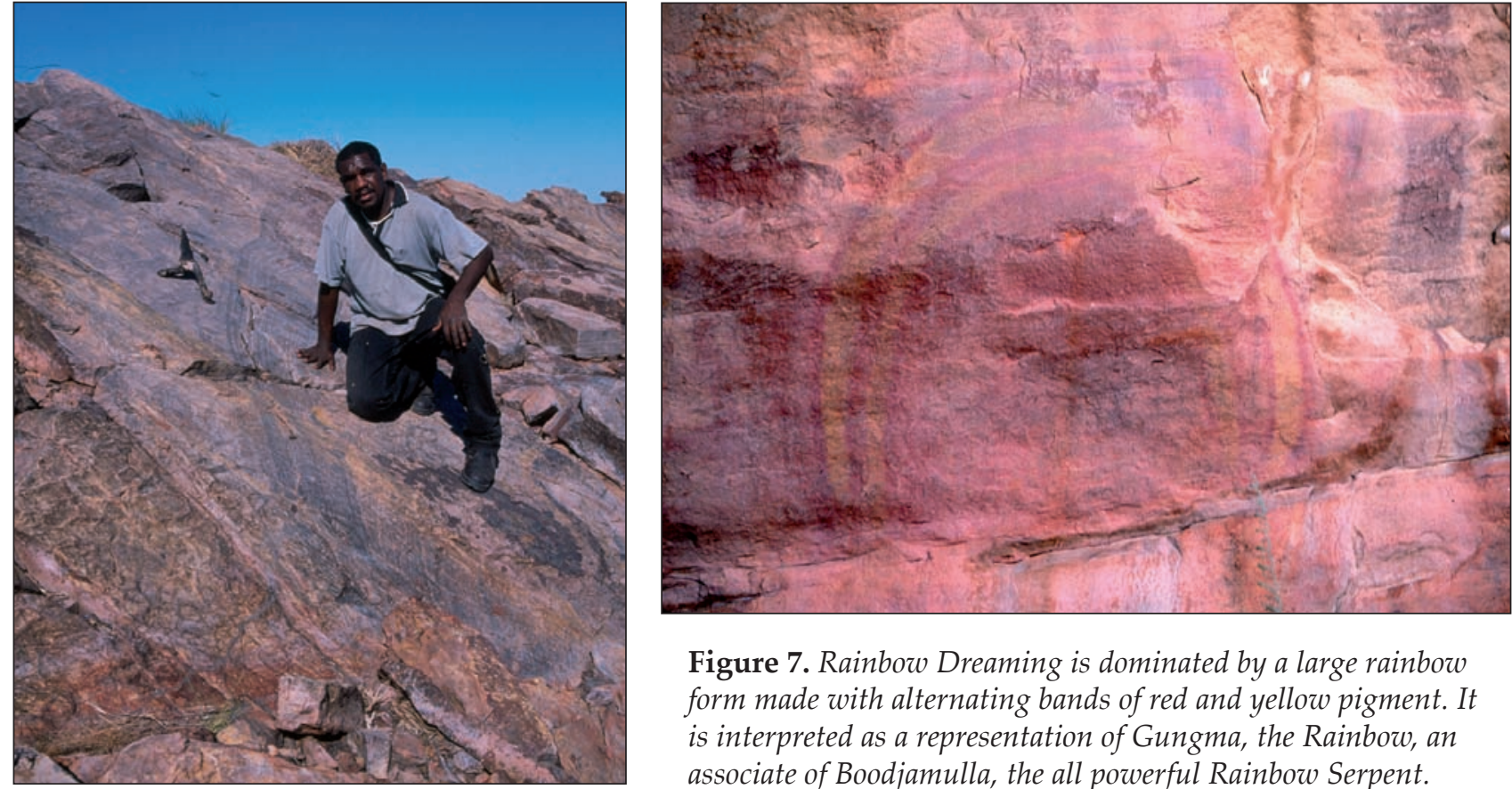

Figure 7. Rainbow Dreaming is dominated by a large rainbow form made with alternating bands of red and yellow pigment. It is interpreted as a representation of Gungma, the Rainbow, an associate of Boodjamulla, the all powerful Rainbow Serpent.

Figure 6. The top of the escarpment above Lilydale Spring and the Rainbow Serpent painting has lengthy seams of coloured bedrock, as Casey Aplin illustrates.
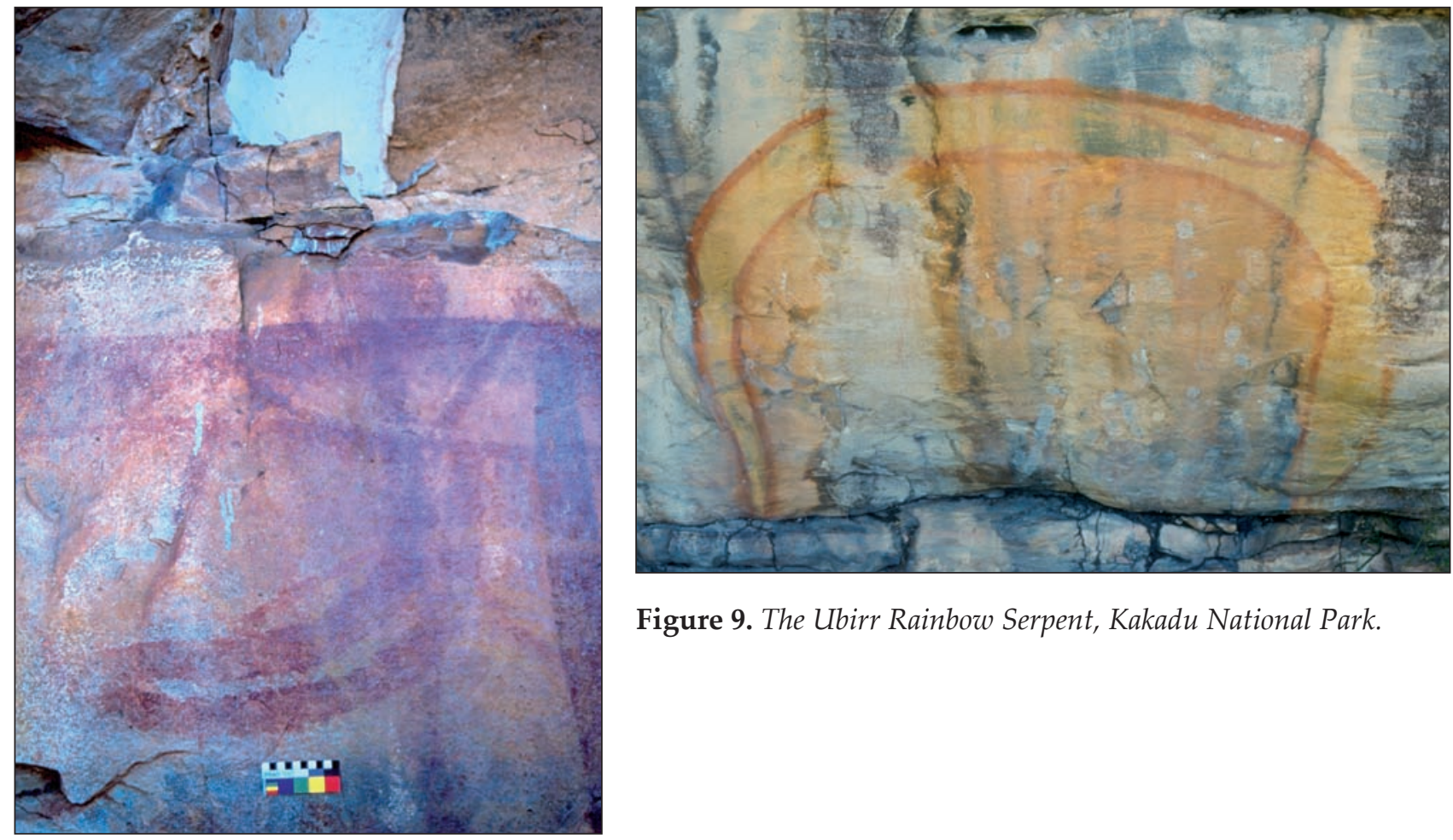

Figure 9. The Ubirr Rainbow Serpent, Kakadu National Park.

Figure 8. Mulberry composite human-snake from the northern end of the study area. 
Contemporary ethnography among the Waanyi is further complicated by about 130 years of European contact (Slack 2002a,b). In the past 100 years, the pastoral industry has changed population size and mobility, and, with this, the ability of stories, designs and so forth to move, be copied and be shared. Some of the details about the travels of Ancestral Beings, Dreaming tracks and connections between Waanyi and other groups across northern Queensland and the Northern Territory may thus have very recent origins. Thus ethnography needs to be used cautiously alongside formal methods of analysis in order better to understand rock art, raw material used for some stone tool production and other aspects of the past (Chippindale \& Taçon 1998). Furthermore, it always has to be kept in mind that meaning continually changes and that imagery is multivocal and multivalent, with different meanings relating to specific images at the same time and through time. Meaning is also contextual and often layered: it varies according to who is interpreting and to whom they are interpreting, with access to various levels of meaning dependent on sex, age, status, knowledge of tradition, contexts of initiation and other factors.

Keeping all of this in mind, we still can conclude many different things about colour use over time. First of all, colour in landscapes, boulders and raw material for stone tool manufacture has influenced the Waanyi variant of Rainbow Serpent depiction, with the iconography of this key Ancestral Being much more rainbow-like than snake-like or composite being-like than elsewhere in Australia. Secondly, the extreme nature of the colourful banded geology of the Lilydale Spring site was a signal as to where best to place the largest and most significant Rainbow Serpent rock painting. Third, Rainbow Serpent images, stories and sites, as well as brightly coloured pigments, are today associated with concepts of Ancestral power, creation and procreation. These associations probably were important for at least 1000 years and perhaps as much as 3500 years but, beyond that time, both the archaeology and the ethnography tell us little.

These conclusions are important for researchers in other parts of the world as they highlight limitations to the use of ethnography, problems of interpretation associated with a general lack of reliable and, or, accurate rock-art dates and limits to types of meaning formal archaeological analysis can reveal. Yet this case study suggests that some local iconographies, cosmologies and symbol systems may have connections to local geology, topography and environment. In terms of the archaeology of colour, changes in rock art, the use of pigment at sites, the use of colourful stone for tools and the siting in relation to colourful parts of local landscapes can possibly give us access to another level of meaning among both ancient and recent cultures. As Jones \& Bradley $(1999,112)$ note, 'The world we inhabit is full of colour, yet we tend to forget that when we study the past'. They also note that colour was a major structuring principle among many early European societies but that this needs further investigation. The challenge for archaeologists, thus, is to find new ways to explore colour use that in some way allow us to make sense of it from both the perspective of the period under investigation and the present. In this way, we can 'come a little closer to appreciating the visual and intellectual worlds of past societies' (Jones \& Bradley 1999, 114), one of the holy grails of cognitive, symbolic and other forms of archaeology. Colour is also important not only in terms of revealing new aspects of meaning about the past but also, more generally, in terms of how material culture, images and the application of pigment or paint has played multidimensional roles in meaning-making for at least 40,000 years.

$$
\begin{array}{r}
\text { Paul S.C. Taçon } \\
\text { School of Arts } \\
\text { Griffith University } \\
\text { Gold Coast Campus } \\
\text { Queensland } 4222 \\
\text { Australia } \\
\text { Email:p.tacon@griffith.edu.au }
\end{array}
$$

\section{Acknowledgements}

I would like to thank the Waanyi community for allowing us to undertake research and for their friendship and generosity. I especially thank Peter Bell, Richard Brookdale, Lenny Cubbie, Jackson Diamond and Eric King for information about rock-art designs, sites, landscapes and Ancestral Beings. Casey Aplin, Harry Bergen, Del Bergen, Melissa Cairns, Des Carlton, Barry Dick, Gadrian George, Nancy George, Bradley King, Eunice O'Keefe, Warren O'Keefe and Daniella Walden are also thanked for assistance in and out of the field. Mike Archer, Andrew Border, Judith Field, Richard Fullagar, Barry Lewis and Michael Slack are thanked for various forms of support and, last but not least, my trusty field assistant Adam Brumm is thanked for hard work, stimulating conversation and companionship. The Australian Museum, Griffith University, the University of Sydney and the Queensland Environmental Protection Authority provided logistical and other support for various stages of this research, which was funded by an Australian Research Council Linkage Grant (LP0211430). I am grateful to Diana Young for inviting me to participate in her symposium, 'Re-materialising colour', which gave me 
the incentive to piece this paper together. An initial version was presented at the Australian National University. No restricted or secret-sacred information or imagery has been included in this article. Waanyi elders listed above gave permission to publish information in this article when it was collected in 2002 and subsequently, including in July 2007. Richard Fullagar, Peter Hiscock and two anonymous referees are thanked for comments that improved this article.

\section{References}

Barham, L.S., 2002. Systematic pigment use in the Middle Pleistocene of South-central Africa. Current Anthropology 43, 181-90.

Border, A., 1988. An Archaeological Survey in the Lawn Hill and Mussebrook Creek area, Northwestern Queensland Highlands. Unpublished manuscript, Queensland Department of Environment \& Heritage.

Border, A., 1989. An Archaeological Survey on Lawn Hill and Bowthorn Stations, Northwestern Queensland. Unpublished manuscript, Heritage Section, Queensland Department of Environment \& Heritage.

Bowler, J.M., H. Johnston, J.M. Olley, J.R. Prescott, R.G. Roberts, W. Shawcross \& N.A. Spooner, 2003. New ages for human occupation and climatic change at Lake Mungo, Australia. Nature 421, 837-40.

Brumm, A., 2005. An axe to grind: symbolic considerations of stone axe use in ancient Australia, in Soils, Stones and Symbols: Cultural Perceptions of the Mineral World, eds. N. Boivin \& M.A. Owoc. London: UCL Press, 143-63.

Chaloupka, G., 1993. Journey in Time. Chatswood: Reed.

Chaloupka, G., N. Kapirigi, B. Nayidji \& G. Namingum, 1985. Cultural survey of Balawurru, Deaf Adder Creek, Amarrkananga, Cannon Hill and the Northern Corridor: a Report to the Australian National Parks \& Wildlife Service. Unpublished manuscript, Australian National Parks \& Wildlife Service and the Museum \& Art Galleries Board of the Northern Territory.

Changizi, M.A., Q. Zhang \& S. Shimojo, 2006. Bare skin, blood and the evolution of primate colour vision. Biology Letters 2, 217-21 (DOI: 10.1098/rsbl.2006.0440).

Chippindale, C. \& P.S.C. Taçon (eds.), 1998. The Archaeology of Rock-Art. Cambridge: Cambridge University Press.

Cole, N., 2005. Review. Australian Archaeology 60, 76-8.

Corbett, L., 2001. The Dingo in Australia and Asia. Marleston: J.B. Books.

David, B., 2002. Landscapes, Rock-Art and the Dreaming: an Archaeology of Preunderstanding. London: Leicester University Press.

Davidson, I., 1993. Archaeology in the Selwyn Ranges, in People of the Stone Age: Hunter-Gatherers and Early Farmers, ed. G. Burenhult. New York (NY): Harper Collins, 210-11.

Department of Environment \& Heritage, 2006. Ubirr Art Site. Australian Government. www.deh.gov.au/parks/ kakadu/artculture/art/ubirr.html (15 August 2006).
Dymock, J., 1982. Historical Material Relevant to Nicholson River Claim Area. Unpublished manuscript, Northern Land Council, Darwin.

Dymock, J., 1993. Something Deep and Rich: Indigenous and Post-contact Environment and Heritage Materials Relevant to the Lawn Hill/Riversleigh District of Queensland. Unpublished manuscript, Queensland Department of Environment \& Heritage.

Fernandez, A.A. \& M.R. Morris, 2007. Sexual selection and trichromatic color vision in primates: statistical support for the pre-existing bias hypothesis. American Naturalist 170, 10-20 (DOI: 10.1086/518566).

Gillespie, D., 1982. The Rock Art and Archaeological Sites of Ubirr, Kakadu National Park. Unpublished manuscript, Australian National Parks \& Wildlife Service, Jabiru.

Gunn, R.G., 2003. Arrernte rock-art: interpreting physical permanence in a changing social landscape. Australian Aboriginal Studies (2003), 52-73.

Gunn, R.G. \& R.L. Whear, 2007. The Jawoyn rock art and heritage project. Rock Art Research 24, 5-20.

Haskovec, I., 1993. Rock art, languages and archaeology of the Top End of Australia, in Rock Art Studies: the Post-Stylistic Era or Where Do We Go from Here?, eds. M. Lorblanchet \& P. Bahn. Oxford: Oxbow, 195-202.

Hayes, L. \& A. Border, 1997. Waanyi Cultural Sites on Elizabeth Creek, Musslebrook Creek, Arthur Creek and Hartness Springs, northwest Queensland. Unpublished manuscript, Queensland Department of Environment (Northern Region).

Henshilwood, C.S., F. d’Errico, R. Yates, Z. Jacobs, C. Tribolo, G.A.T. Duller, N. Mercier, J.C. Sealy, H. Valladas, I. Watts, I. \& A.G. Wintle, 2002. Emergence of modern human behavior: Middle Stone Age engravings from South Africa. Science 295, 1278-80.

Hiscock, P., 1988. Prehistoric Settlement Patterns and Artefact Manufacture at Lawn Hill, Northwest Queensland. Unpublished PhD thesis. University of Queensland, Brisbane.

Isbell, L.A., 2006. Snakes as agents of evolutionary change in primate brains. Journal of Human Evolution 51, 1-35.

Jones, A. \& R. Bradley, 1999. The significance of colour in European archaeology. Cambridge Archaeological Journal 9(1), 112-14.

Jones, A. \& G. MacGregor. 2002. Colouring the Past: the Significance of Colour in Archaeological Research. Oxford: Berg.

Lewis, D., 1988. The Rock Paintings of Arnhem Land: Social, Ecological, and Material Culture Change in the Post-Glacial Period (British Archaeological Reports International Series 415). Oxford: Archaeopress.

McBrearty, S. \& A. Brooks, 2000. The revolution that wasn't: a new interpretation of the origin of modern human behavior. Journal of Human Evolution 39, 453-563.

McConvell, P., 1996. Backtracking to Babel: the chronology of Pama-Nyungan expansion in Australia. Archaeology in Oceania 31, 125-44.

McConvell, P. \& N. Thieberger, 2005. Languages past and present, in Macquarie Atlas of Indigenous Australia, eds. 
B. Arthur \& F. Morphy. Sydney: Macquarie University, 78-87.

McGlone, M.S., A.P. Kershaw \& V. Markgraf, 1992. El Nino/Southern Oscillation climatic variability in Australasian and South American paleoenvironmental records, in El Nino: Historical and Paleoclimatic Aspects of the Southern Oscillation, eds. H.F. Diaz \& V. Markgraf. Cambridge: Cambridge University Press, 435-62.

Moore, M., 2003. Flexibility of stone tool manufacturing methods on the Georgina River, Camooweal, Queensland. Archaeology in Oceania 38, 23-36.

Moore, M., 2004. The tula adze: manufacture and purpose. Antiquity 78, 61-73.

Morey, D., 2006. Burying key evidence: the social bond between dogs and people. Journal of Archaeological Science 33, 158-75.

Morphy, H., 1989. From dull to brilliant: the aesthetics of spiritual power among the Yolgnu. Man 24, 21-39.

Morphy, H., 1991. Ancestral Connections: Art and an Aboriginal System of Knowledge. Chicago (IL): University of Chicago Press.

Morwood, M.J., 1977. Art and Stone: Towards a Prehistory of Central and Western Queensland. Unpublished PhD thesis. Australian National University, Queensland.

Mountford, C.P., 1956. Art, Myth and Symbolism: Records of the American-Australian expedition to Arnhem Land, vol. 1. Melbourne: Melbourne University Press.

Mulvaney, J. \& J. Kamminga, 1999. Prehistory of Australia. Sydney: Allen \& Unwin.

Osborne, H.F., 1916. Men of the Old Stone Age: their Environment, Life and Art. 2nd edition. New York (NY): Charles Scribner's Sons.

Rose, D.B., 1992. Dingo Makes Us Human: Life and Land in an Aboriginal Australian culture. Cambridge: Cambridge University Press.

Rose, D.B., 2002. The Dead, the Missing, the Lost, and the Voiceless: Some Thoughts on Extinction from a Dingo Perspective. Paper presented at the Ninth Conference on Hunting \& Gathering (CHAGS), Edinburgh; www. abdn.ac.uk/chags9/1-rose.htm, September 2002.

Scarre, C., 1999. Viewpoint: what meaning had colour in early societies? Cambridge Archaeological Journal 9(1), 109 .

Slack, M., 2002a. Aboriginal Responses to European Contact in Northwestern Queensland. Unpublished MA thesis. Canberra: Australian National University.

Slack, M., 2002b. The 'Plains of Promise' revisited: a reassessment of the frontier in north western Queensland. Journal of Australian Studies 75, 71-83.

Slack, M., R.L.K. Fullagar, J.H. Field \& A. Border, 2004. New Pleistocene ages for backed blade artefact technology in Australia. Archaeology in Oceania 39, 131-7.

Slack, M., R. Fullagar, A. Border, J. Diamond \& J. Field, 2005. Late Holocene occupation at Bunnengalla 1, Musselbrook Creek, northwest Queensland. Australian Archaeology 60, 54-8.

Taçon, P.S.C., 1989a. Art and the essence of being: the symbolic and economic aspects of fish among the peoples of western Arnhem Land, Australia, in Animals into Art, ed. H. Morphy. London: Unwin Hyman, 236-50.

Taçon, P.S.C., 1989b. From Rainbow Snakes to 'X-ray' Fish: the Nature of the Recent Rock Painting Tradition of Western Arnhem Land, Australia. Unpublished PhD thesis, Australian National University, Canberra.

Taçon, P.S.C., 1989c. From the 'Dreamtime' to the present: the changing role of Aboriginal rock paintings in western Arnhem Land, Australia. Canadian Journal of Native Studies 9, 317-39.

Taçon, P.S.C., 1991. The power of stone: symbolic aspects of stone use and tool development in western Arnhem Land, Australia. Antiquity 65, 192-207.

Taçon, P.S.C., 1992. 'If you miss all this story, well bad luck': rock art and the validity of ethnographic interpretation in western Arnhem Land, Australia, in Rock Art and Ethnography: Proceedings of the Ethnography Symposium, eds. M.J. Morwood \& D.R. Hobbs. Melbourne: Australian Rock Art Research Association, 11-18.

Taçon, P.S.C., 2005. Ochre, clay, stone and art: the symbolic importance of minerals as life-force among Aboriginal peoples of northern and central Australia, in Soils, Stones and Symbols: Cultural Perceptions of the Mineral World, eds. N. Boivin \& M.A. Owoc. London: UCL Press, 31-42.

Taçon, P.S.C., 2006. Behaviourally modern at 300,000 вP: was my ancestor brighter than yours? Before Farming: the Archaeology \& Anthropology of Hunter-Gatherers 2006/2 article 3, 144-52.

Taçon, P.S.C. \& C. Chippindale, 1994. Australia's ancient warriors: changing depictions of fighting in the rock art of Arnhem Land, N.T. Cambridge Archaeological Journal 4(2), 211-48.

Taçon, P.S.C. \& C. Chippindale. 2001. Transformation and depictions of the First People: animal-headed beings of Arnhem Land, N.T., Australia, in Theoretical Perspectives in Rock Art Research, ed. K. Helskog. Oslo: Novus, 175-210.

Taçon, P.S.C. \& C. Chippindale, in press. Changing places: north Australian rock-art transformations 4000-6000 вг, in Time and Change: Archaeological and Anthropological Perspectives on the Long Term in HunterGatherer Societies, eds. H. Maschner, D. Papagianni \& R. Layton. Oxford: Oxbow.

Taçon, P.S.C. \& C. Pardoe, 2002. Dogs make us human. Nature Australia 27(4), 53-61.

Taçon, P.S.C., M. Wilson \& C. Chippindale, 1996. Birth of the Rainbow Serpent in Arnhem Land rock art and oral history. Archaeology in Oceania 31, 103-24.

Taylor, L., 1990. The Rainbow Serpent as visual metaphor in western Arnhem Land. Oceania 60, 329-44.

Taylor, L., 1996. Seeing the Inside: Bark Painting in Western Arnhem Land. Oxford: Oxford University Press.

Us Mob, 2006. Traditional Stories, 8.2. www.usmob.com. au/factsheets/Fact_Sheet_08.pdf (15 August 2006).

Van der Meer, A., 1997. Widtheringyapa: a Predictive Model for the Archaeology of the Riversleigh Management Unit Lawn Hill National Park. Unpublished BA 
Honours thesis, University of New South Wales.

Walsh, G., 1982. Aboriginal Sites of the Lawn Hill Gorge Area: a Preliminary Report. Unpublished manuscript, Queensland National Parks \& Wildlife Service.

Walsh, G., 1985. The Archaeological Significance of Lawn Hill Gorge. Unpublished manuscript, Queensland National Parks \& Wildlife Service.

Young, D., 2006. The colours of things, in Handbook of Material Culture, eds. C. Tilley, W. Keane, S. Kuechler-Fogden, M. Rowlands \& P. Spyer. London: Sage, 173-85.

\section{Author biography}

Paul S.C. Taçon is Professor of Anthropology and Archaeology in the School of Arts, Griffith University, Queensland. He has conducted archaeological and ethnographic fieldwork since 1980 and has over 65 months field experience on four continents. Professor Taçon has co-edited three books (including The Archaeology of Rock-art with Christopher Chippindale) and published over 135 academic and popular papers on prehistoric art, body art, material culture, colour, cultural evolution, identity and contemporary Indigenous issues. 